\title{
Effect of environmental conditions on methane production and emission from paddy soil
}

\author{
Shang-Shyng Yang*, Hsiu-Lan Chang \\ Department of Agricultural Chemistry, National Taiwan University, Taipei 10617, Taiwan
}

Accepted 5 February 1998

\begin{abstract}
Methane production and emission from paddy soil in laboratory experiments were affected by sterilization, temperature, organic matter supplementation, urea application, oxygen concentration, water content, soil $\mathrm{pH}$ and light intensity. Methane production was negligible in sterilized soil, whereas each gram of natural soil produced a daily maximum of $344 \mu \mathrm{g}$ methane. There were two methane production peaks, one at $37^{\circ} \mathrm{C}$, the other at $60^{\circ} \mathrm{C}$. There was a positive linear correlation between methane production and incubation temperature from 15 to $37^{\circ} \mathrm{C}$, and a negative linear correlation between 37 and $50^{\circ} \mathrm{C}$. Methane production increased with the amount of rice straw supplementation. Green manure, corncob, xylan, avicel and compost application had a stimulating effect on methane production, whereas glucose, sucrose and urea supplements were inhibitory. Anaerobic conditions and water flooding on the surface of soil favoured methane emission. (C) 1998 Elsevier Science B.V. All rights reserved.
\end{abstract}

Keywords: Methane production; Methane emission; Paddy soil; Temperature; Oxygen; Rice straw

\section{Introduction}

Methane is an important greenhouse gas because of its strong infrared absorption band characteristics, and recent worldwide atmospheric increases, which is contributing to changes in atmospheric chemistry and may cause global warming (Bouwman, 1991). The major sites of methane production are rice paddies, ruminants, landfills, natural wetlands and sediments (Ehhalt and Schmidt, 1978; Yang et al., 1994; Yang and Chang, 1997; Yang, 1998). About $80 \%$ of

*Corresponding author. Tel.: 008862 23621519; fax: 008862 23679827; e-mail: ssyang@ccms.ntu.edu.tw methane is produced biologically by a group of strictly anaerobic bacteria in highly reduced environments (Ehhalt and Schmidt, 1978). Temperature, organic matter content, $\mathrm{pH}$, moisture content and redox potential of soil are major factors affecting methane production (Sass et al., 1991; Kimura et al., 1993; Moore and Dalva, 1993; Yang et al., 1994; Cao et al., 1995; Yang and Chang, 1997).

Rice is a major crop in Taiwan. In 1996, the cultivated areas were 182807 and 164955 ha for the first and the second crop seasons, respectively. The methane flux fluctuates markedly with environmental conditions. Recently, studies on the methane emission from rice fields have made significant pro- 
gress in relation to the problem of global warming (Sass et al., 1991; Delwiche and Cicerone, 1993; Shin et al., 1995). This work focuses on the effect of temperature, organic matter supplementation, urea application, oxygen concentration, water content, $\mathrm{pH}$ and light intensity on methane production from paddy soil.

\section{Materials and methods}

\subsection{Soil}

Langyang (located in I-lan County, Taiwan) Malintso sandy loam soil was used in these laboratory experiments and the properties of the test soil were: $\mathrm{pH}, 6.0 \pm 0.1$; organic matter, $29.6 \pm 0.8 \mathrm{~g} \mathrm{~kg}^{-1}$ (dry weight); total nitrogen, $1.9 \pm 0.3 \mathrm{~g} \mathrm{~kg}^{-1}$ (dry weight); and sand: clay: silt $=50.6: 7.1: 41.6$. All the experiments were performed in triplicate.

\subsection{Rice straw}

Taigang No. 10 Indica rice straw was air-dried and crushed and the powder was passed through a 40 mesh seive. Rice straw contained (dry weight) cellulose $387 \mathrm{~g} \mathrm{~kg}^{-1}$, hemicellulose $183 \mathrm{~g} \mathrm{~kg}^{-1}$, lignin $150 \mathrm{~g}$ $\mathrm{kg}^{-1}$, total nitrogen $6.6 \mathrm{~g} \mathrm{~kg}^{-1}$ and ash $122 \mathrm{~g} \mathrm{~kg}^{-1}$.

\subsection{Soil sterilization and methane production}

Langyang soil $10 \mathrm{~g}$ (10 mesh) was thoroughly mixed with $0.2 \mathrm{~g}$ rice straw powder $(40 \mathrm{mesh})$ and put into a $125 \mathrm{ml}$ serum bottle. $20 \mathrm{ml}$ deionized water was added to the mixture and then sterilized at $121^{\circ} \mathrm{C}$ for $40 \mathrm{~min}$. After sterilization, the serum bottle was sealed with a butyl rubber stopper, and incubated at $30^{\circ} \mathrm{C}$ for 45 days. Every 3 to 5 days, the gas $(1.0 \mathrm{ml})$ in the head space was withdrawn and $0.3 \mathrm{ml}$ was injected into a glass column $(0.26 \mathrm{~mm} \times 2.0 \mathrm{~m})$ which was packed with Porapak Q (80/100 mesh) on a Shimadzu 14 A Gas Chromatograph (Shimadzu, Japan). Column temperature was set at $100^{\circ} \mathrm{C}$, injection and detector temperatures were set at $130^{\circ} \mathrm{C}$. Methane concentration was calculated from a head space volume, moisture content and the amount of soil used (Chang and Yang, 1997). Non-sterilized natural soil was also incubated as the control.

\subsection{Organic substances and methane production}

In anaerobic conditions, most organic matter converts to methane. Glucose (monosaccharide), sucrose and cellobiose (disaccharide), starch and xylan (polysaccharide), carboxyl methyl cellulose and Avicel (cellulose derivative), rice straw and corncob (crop residue), green manure, pig manure, sawdust and compost (agricultural waste), peptone and casein (nitrogenous compound) were chosen as the organic substances and applied to the test soil for methane production.

Ten gram of Langyang soil (10 mesh) was thoroughly mixed with $0.0,0.2,0.4,0.6,0.8,1.0,1.5$ and $2.0 \mathrm{~g}$ rice straw powder (40 mesh) (or $0.2 \mathrm{~g}$ other organic substances), and put into a $125 \mathrm{ml}$ serum bottle. $20 \mathrm{ml}$ deionized water was added and the serum bottle was sealed with a butyl rubber stopper, flushed with oxygen-free nitrogen gas and incubated at 30 or $37^{\circ} \mathrm{C}$ for 45 days, respectively. Methane concentration was determined every 3-5 days and methane production was estimated by the head space method.

\subsection{Environmental conditions and methane production}

Langyang soil $10 \mathrm{~g}$ (10 mesh) was thoroughly mixed with $0.2 \mathrm{~g}$ rice straw powder $(40 \mathrm{mesh})$, and then twenty $\mathrm{ml}$ deionized water was put into a $125 \mathrm{ml}$ serum bottle. The serum bottle was sealed with a butyl rubber stopper, flushed with oxygen-free nitrogen gas, and the following experiments were designed to test the influence of the various factors on methane production and emission from paddy soil. Methane concentration was determined every 3-5 days by the head space method (Chang and Yang, 1997).

\section{(1). Incubation temperature:}

To evaluate the effect of incubation temperature on methane production of mesophilic and thermophilic methanogens in the paddy soil, serum bottles were incubated at 4, 15, 20, 25, 28, 30, 35, 37, 40, 45, 50, 55, and $60^{\circ} \mathrm{C}$ for 45 days.

(2). Temperature adaptation:

To investigate the fluctuation of temperature on methane production, serum bottles were incubated at $30^{\circ} \mathrm{C}$ for 11 days, and then shifted to $4,10,15$, 
$20,25,28,30,35,37,40,45,50,55$, and $60^{\circ} \mathrm{C}$ for another $24 \mathrm{~h}$ incubation.

(3). Oxygen effect:

All methanogens are strictly and obligately anaerobic. The effect of oxygen on methane production was carried out as following. One set of serum bottles was flushed with oxygen-free nitrogen gas as the anaerobic treatment and the other set was sealed in ambient air without a flushing treatment as the aerobic treatment. Both sets of serum bottles were incubated at $30^{\circ} \mathrm{C}$ for 45 days.

(4). Initial soil $\mathrm{pH}$ :

Most of the methanogenic bacteria grow at a $\mathrm{pH}$ near neutrality. The original soil $\mathrm{pH}$ was 6.6 , and it was adjusted with $0.1 \mathrm{M} \mathrm{NaOH}$ or $0.1 \mathrm{M} \mathrm{HCl}$ to $\mathrm{pHs}$ 3.2, 4.3, 5.1, 6.0, 6.6, 7.7, 8.1, 8.7 and 9.3 for methane production at $30^{\circ} \mathrm{C}$ for 45 days.

\section{(5). Water content:}

Water content is a very important factor in methane production. The soil water content was adjusted with deionized water to $1.0,9.1,16.7,23.1,28.6,33.3$, $37.5,41.2,50.0,60.0$ and $66.7 \%$ moisture for methane production at $30^{\circ} \mathrm{C}$ for 45 days.

(6). Water depth:

Methane production had a positive correlation with depth of water flooding in a subarctic boreal marsh (Sebacher et al., 1986). The depth of water on the soil surface was adjusted to 0.0, 0.5, 1.0, 2.0, 3.0, 4.0 and $5.0 \mathrm{~cm}$ with deionized water, and serum bottles with different depths of water were incubated at $30^{\circ} \mathrm{C}$ for 45 days.

(7). Light intensity:

To study the effect of light intensity on methane production from paddy soil, serum bottles were flushed with air or oxygen-free nitrogen gas, and then incubated in the dark, at 1,000-2,000 Lux for 2-3 h daily, or at 5,000-7,000 Lux light intensity for $15 \mathrm{~h}$ daily at $30^{\circ} \mathrm{C}$ for 45 days, respectively.

\section{(8). Urea supplement:}

Urea is sometimes used for a top dressing fertiliser in rice cultivation. Each bottle was supplemented with $0.0,1.0,2.0,3.0,4.0,5.0,10$ and $20 \mathrm{mg}$ urea, and serum bottles were incubated at $30^{\circ} \mathrm{C}$ for methane production.

\subsection{Analytical methods}

(1). $p H$ : Soil $\mathrm{pH}$ was determined directly.
(2). Water content: Water content was determined gravimetrically with the oven drying method of Gardner (1982).

(3). Total nitrogen: Total nitrogen was measured by the modified Kjeldahl method (Yang et al., 1991)

(4). Total carbon: Total carbon was analyzed by the wet oxidation Walkley-Black method, and organic matter content was calculated as $\mathrm{C} \times 1.724$ (Nelson and Sommers, 1982).

(5). Cellulose: Cellulose content was determined by the loss on incineration of dried residue remaining after digestion of the sample with ethanol, dilute $\mathrm{H}_{2} \mathrm{SO}_{4}$ and $\mathrm{NaOH}$ (Kawauchi, 1990).

(6). Hemicellulose: Hemicellulose content was measured by the acidic precipitate of alkali extraction of the sample (Kawauchi, 1990).

(7). Lignin: Lignin content was analyzed by the loss on incineration of dried residue remaining after digestion of cellulose with $72 \% \mathrm{H}_{2} \mathrm{SO}_{4}$ (Kawauchi, 1990).

(8). Ash: Ash content was determined gravimetrically after $16-20 \mathrm{~h}$ at $550-600^{\circ} \mathrm{C}$.

(9). Water-holding capacity: Water-holding capacity was determined by the modified cylinder method (Cheng et al., 1982).

(10). Statistical analysis: Treatments were replicated three times and flux data subjected to analysis of variance and Duncan's multiple range test $(p=0.05)$ using the Statistical Analysis System (SAS Institute, 1988).

\section{Results}

\subsection{Effect of sterilization on methane production}

Methane production rate was practically negligible

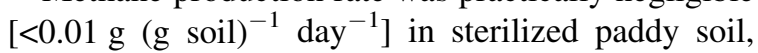
whereas it increased with incubation time in natural paddy soil and the maximal methane production rate was $344.4 \mu \mathrm{g}\left(\mathrm{g} \mathrm{soil}^{-1} \mathrm{day}^{-1}\right.$ at $12 \mathrm{th}$ day. The daily average methane production rate was $13 \mathrm{ng}$ $(\mathrm{g} \mathrm{soil})^{-1}$ and $130 \mu \mathrm{g}(\mathrm{g} \mathrm{soil})^{-1}$ for sterilized and natural soils for 45 days incubation, respectively. Total methane production was $0.6 \mu \mathrm{g}$ and $5.8 \mathrm{mg}$ for 45 days incubation in sterilized and natural soils, respectively. 


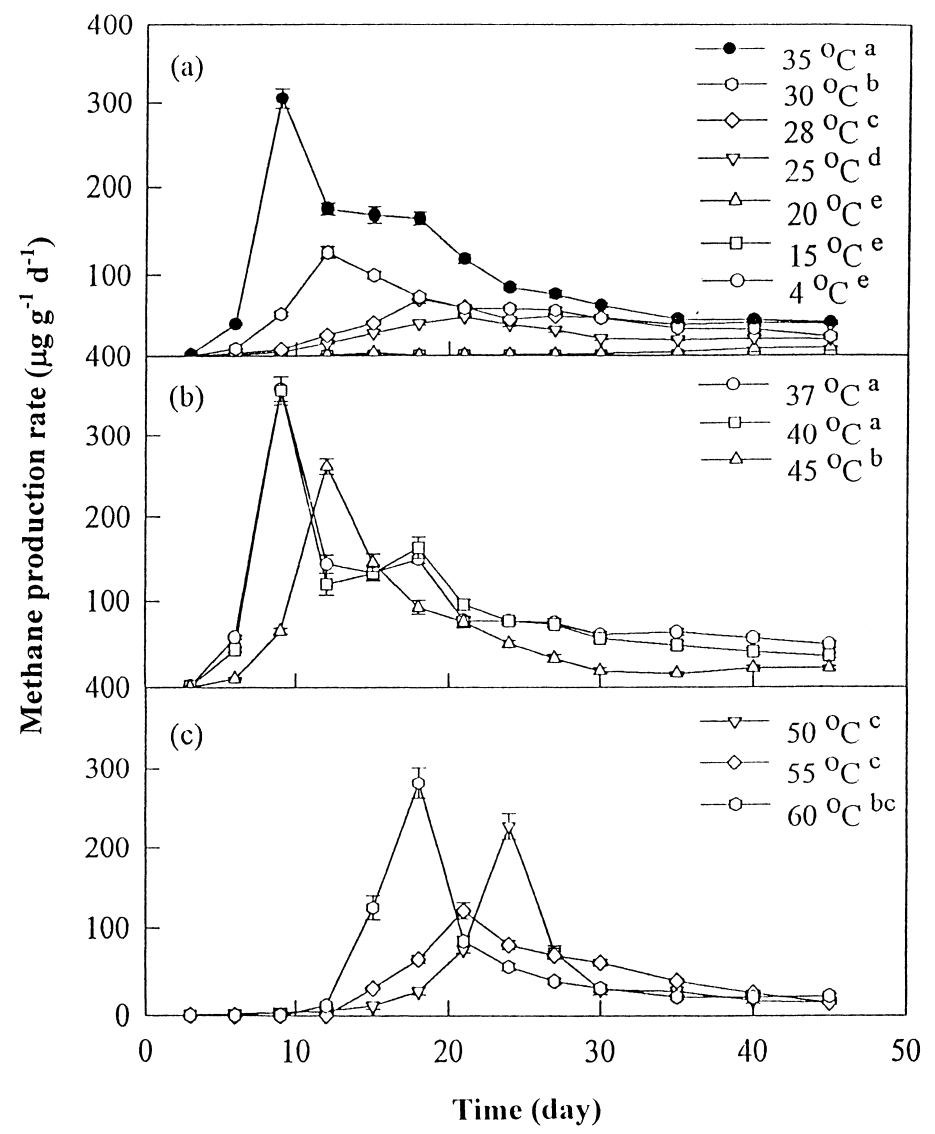

Fig. 1. Effect of incubation temperature on methane production rate from paddy soil. Symbol labels in the figure that do not share the same alphabetic superscript are significantly different at 5\% level according to Duncan's multiple range test. (a) Temperature range $4-35^{\circ} \mathrm{C}$; (b) Temperature range $37-45^{\circ} \mathrm{C}$; (c) Temperature range $50-60^{\circ} \mathrm{C}$.

\subsection{Effect of incubation temperature on methane production}

Fig. 1 presents methane production rate of paddy soil at different incubation temperatures. The maximal methane production rate was at $37^{\circ} \mathrm{C}$. Each gram of soil produced a daily maximum of $359.4 \mu \mathrm{g}$ methane. Methane production rate decreased and the time for maximal methane production was retarded when the incubation temperature exceeded $40^{\circ} \mathrm{C}$ or fell below $35^{\circ} \mathrm{C}$.

There were two methane production peaks, one at $37^{\circ} \mathrm{C}$ and the other at $60^{\circ} \mathrm{C}$. Each gram of soil produced $4.3 \pm 0.2 \mathrm{mg}$ methane at $37^{\circ} \mathrm{C}$. There was a positive linear correlation between total methane production $(Y)$ and incubation temperature $(X)$ between
15 and $37^{\circ} \mathrm{C} ; Y=0.22 X-3.94\left(r^{2}=0.93\right)$, although it was negative between 37 and $50^{\circ} \mathrm{C} ; Y=-0.21 X+$ $12.15\left(r^{2}=0.98\right)$. There was another methane production peak when the incubation temperature was at $60^{\circ} \mathrm{C}$ for the growth of thermophilic methanogens. Each gram of soil produced $2.2 \pm 1.0 \mathrm{mg}$ methane at $60^{\circ} \mathrm{C}$.

\subsection{Effect of temperature adaptation on methane production}

Table 1 lists the effect of temperature adaptation on methane production. Methane production rate at the shift temperature increased from 4 to $37^{\circ} \mathrm{C}$ when the soil was originally incubated at $30^{\circ} \mathrm{C}$ for 12 days. Methane production had the maximal value at $37^{\circ} \mathrm{C}$, 
Table 1

Effect of temperature adaptation on methane production in paddy soil $^{1}$

\begin{tabular}{lcl}
\hline $\begin{array}{l}\text { Temperature } \\
\left({ }^{\circ} \mathrm{C}\right)\end{array}$ & $\begin{array}{l}\text { Methane production rate } \\
\left(\mu \mathrm{g} \mathrm{g}^{-1} \mathrm{~d}^{-1}\right)\end{array}$ & Production factor \\
\hline $30 \rightarrow 4^{3}$ & $0.3 \pm 0.04^{\mathrm{i}}$ & 0.00 \\
$30 \rightarrow 10$ & $2.1 \pm 0.54^{\mathrm{i}}$ & 0.01 \\
$30 \rightarrow 15$ & $5.9 \pm 1.21^{\mathrm{i}}$ & 0.03 \\
$30 \rightarrow 20$ & $18.9 \pm 2.08^{\mathrm{h}}$ & 0.10 \\
$30 \rightarrow 25$ & $46.1 \pm 6.09^{\mathrm{f}}$ & 0.25 \\
$30 \rightarrow 28$ & $76.3 \pm 5.49^{\mathrm{e}}$ & 0.41 \\
$30 \rightarrow 30$ & $106.8 \pm 9.35^{\mathrm{d}}$ & 0.57 \\
$30 \rightarrow 35$ & $178.4 \pm 6.67^{\mathrm{b}}$ & 0.95 \\
$30 \rightarrow 37$ & $187.5 \pm 4.92^{\mathrm{a}}$ & 1.00 \\
$30 \rightarrow 40$ & $160.3 \pm 4.08^{\mathrm{c}}$ & 0.86 \\
$30 \rightarrow 45$ & $75.7 \pm 5.72^{\mathrm{c}}$ & 0.40 \\
$30 \rightarrow 50$ & $36.5 \pm 1.19^{\mathrm{g}}$ & 0.19 \\
$30 \rightarrow 55$ & $3.3 \pm 0.89^{\mathrm{i}}$ & 0.02 \\
$30 \rightarrow 60$ & $0.8 \pm 0.23^{\mathrm{i}}$ & 0.01 \\
\hline
\end{tabular}

${ }^{1}$ Mean \pm SD $(n=3)$, in the same row that do not share the same alphabetic superscript are significantly different at 5\% level according to Duncan's multiple range test.

${ }^{2}$ Methane production rate at $37^{\circ} \mathrm{C}$ is 1.00 .

${ }^{3}$ All samples contain $2 \%$ rice straw powder as carbon and energy sources and incubate at $30^{\circ} \mathrm{C}$ for 11 days, and then the samples are shifted to $4-60^{\circ} \mathrm{C}$ for additional $24 \mathrm{~h}$.

then decreased with elevating temperature to $60^{\circ} \mathrm{C}$. It also had a positive linear correlation between methane production rate and shift temperature between 15 and $37^{\circ} \mathrm{C}$; whereas it had a negative linear correlation from 37 to $60^{\circ} \mathrm{C}$.

\subsection{Effect of rice straw supplementation on methane production}

Methane production rate increased linearly with the amount of rice straw supplementation. The maximum values were 938 and $1,582 \mu \mathrm{g}(\mathrm{g} \text { soil })^{-1}$ day $^{-1}$ with $20 \%$ rice straw powder at 30 and $37^{\circ} \mathrm{C}$, respectively (Fig. 2). The average methane production rates were $527.6 \pm 15.3$ and $730.9 \pm 13.8 \mu \mathrm{g}(\mathrm{g} \text { soil })^{-1}$ day $^{-1}$ for 45 days at 30 and $37^{\circ} \mathrm{C}$, respectively.

\subsection{Effect of organic substances on methane production}

Table 2 shows the effect of several organic substances on methane production. Green manure and corncob supplement produced high methane production, followed by xylan, rice straw, pig manure, avicel, carboxyl methyl cellulose, peptone, rice husk compost and sawdust. Supplementation with glucose, sucrose, cellobiose and starch lowered the substrate $\mathrm{pH}$ from the initial $\mathrm{pH} 6.6$ to final $\mathrm{pHs}$ of 3.8-4.9, whereas casein supplementation raised the substrate $\mathrm{pH}$ from an initial $\mathrm{pH}$ of 6.6 to a final $\mathrm{pH}$ of 8.4. Both high and low $\mathrm{pH}$ were unfavourable to methane production.

Fig. 3 shows the effect of urea application on methane production. Methane production decreased and retarded with increasing urea application. Methane production with urea application was not significantly different between 0 and $200 \mathrm{mg} \mathrm{N}$ ( $\mathrm{kg}$ soil) ${ }^{-1}$; however, the value decreased significantly with increasing amount of urea higher than $300 \mathrm{mg} \mathrm{N}(\mathrm{kg} \text { soil })^{-1}$.

\subsection{Effect of oxygen on methane production}

Fig. 4 shows the effect of oxygen on methane production of paddy soil. Anaerobic conditions favoured methane production. Each gram of soil produced daily maxima of 232.3 and $33.6 \mu \mathrm{g}$ methane under anaerobic and aerobic conditions, respectively. In addition, methane production was faster under anaerobic conditions than under aerobic conditions. Total methane production under anaerobic conditions was about 10 times greater than under aerobic conditions.

After 30 days anaerobic incubation, the methane production rate of paddy soil decreased sharply following air-flush treatment. Some 50\%, 85\% and 95\% of methane production was inhibited at 1 st, 2nd and 3rd air-flush treatments, respectively.

\subsection{Effect of water content on methane production}

Methane production was negligible when the water content of the soil was less than $23 \%[<8 \mu \mathrm{g}$ methane (g soil $^{-1}$ for 45 days incubation]. Methane production increased with water content of soil with a maximum at $66.7 \%$ water. There was a positive linear correlation between total methane production and water content of soil from 16.7 to $66.7 \%$. Water holding capacity of Langyang soil was $37.4 \pm 0.9 \%$. Because $23 \%$ water content was equivalent to about $61 \%$ of water holding capacity, this condition was substantially aerobic. Therefore, methane production was small with $23 \%$ water content. However, $50 \%$ and $66.7 \%$ water contents mean more anaerobiosis and so favour production of methane. 


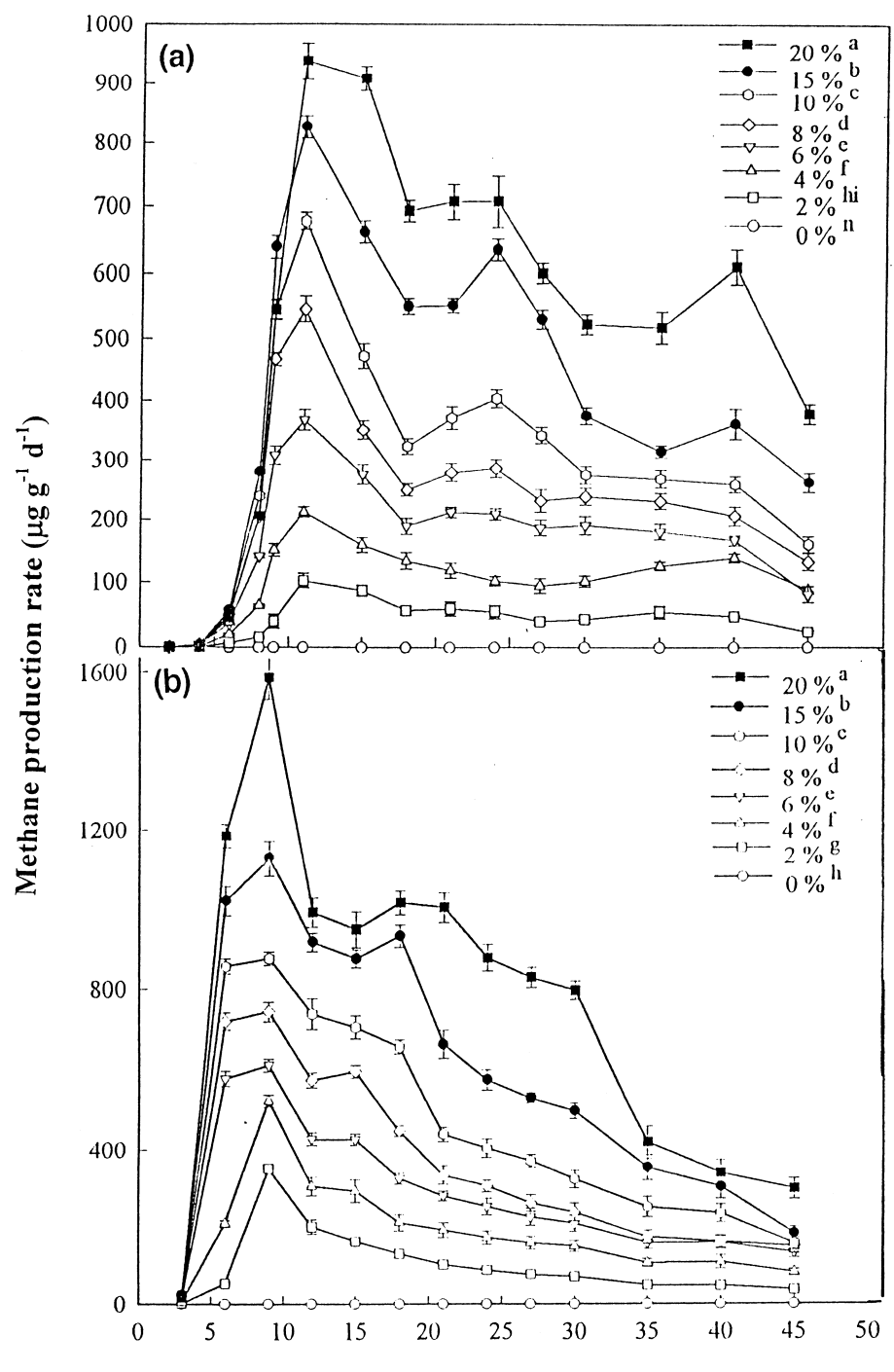

Time (day)

Fig. 2. Effect of rice straw powder supplement (0-20\%) on methane production rate from paddy soil. Symbol labels in the figure that do not share the same alphabetic superscript are significantly different at $5 \%$ level according to Duncan's multiple range test. (a) Incubation at $30^{\circ} \mathrm{C}$; (b) Incubation at $37^{\circ} \mathrm{C}$.

\subsection{Effect of depth of flooding on methane production}

Fig. 5 shows the effect of depth of flooding on methane production of the test soil. The deeper the flooding, the longer the period before the maximal methane production is reached. Both maximum methane production rate and total methane production increased with the depth of water flooding as would be expected for the increasing anaerobic conditions.

\subsection{Effect of initial $\mathrm{pH}$ on methane production}

Each gram of soil daily produced $32.7 \pm 2.2$ to $65.1 \pm 6.4 \mu \mathrm{g}$ methane between initial $\mathrm{pH} 4.3$ and 8.7. Methane production was inhibited when the 
Table 2

Effect of organic substances on methane production in paddy soil ${ }^{1}$

\begin{tabular}{|c|c|c|c|c|c|}
\hline Substance added & $\begin{array}{l}\text { Maximal production } \\
\text { time (day) }\end{array}$ & $\begin{array}{l}\text { Maximal production } \\
\text { rate }\left(\mu \mathrm{g} \mathrm{g}^{-1} \mathrm{~d}^{-1}\right)\end{array}$ & $\begin{array}{l}\text { Average production } \\
\text { rate }\left(\mu \mathrm{g} \mathrm{g}^{-1} \mathrm{~d}^{-1}\right)\end{array}$ & $\begin{array}{l}\text { Cumulative methane in } \\
45 \text { days }\left[\mathrm{mg}(\mathrm{g} \text { soil })^{-1} \text { ] }\right.\end{array}$ & $\begin{array}{l}\text { Final } \\
\mathrm{pH}^{2}\end{array}$ \\
\hline Glucose & 9 & $0.2^{f}$ & $<0.01 \pm 0.001^{\mathrm{f}}$ & $<0.001 \pm 0.000^{f}$ & $3.9 \pm 0.10^{f}$ \\
\hline Sucrose & 9 & $0.1^{\mathrm{f}}$ & $<0.01 \pm 0.001^{\mathrm{f}}$ & $<0.001 \pm 0.000^{\mathrm{f}}$ & $3.8 \pm 0.08^{\mathrm{f}}$ \\
\hline Cellobiose & 12 & $0.1^{\mathrm{f}}$ & $<0.01 \pm 0.01^{\mathrm{f}}$ & $<0.001 \pm 0.000^{\mathrm{f}}$ & $4.0 \pm 0.15^{\mathrm{f}}$ \\
\hline Starch & 12 & $0.2^{f}$ & $<0.01 \pm 0.001^{\mathrm{f}}$ & $<0.001 \pm 0.000^{\mathrm{f}}$ & $4.9 \pm 0.10^{\mathrm{c}}$ \\
\hline Xylan $^{3}$ & 12 & $397.7^{\mathrm{a}}$ & $225.8 \pm 11.78^{\mathrm{a}}$ & $10.2 \pm 0.53^{\mathrm{a}}$ & $7.6 \pm 0.05^{\mathrm{b}}$ \\
\hline Xylan $^{4}$ & 12 & $294.6^{\mathrm{b}}$ & $89.8 \pm 19.11^{\mathrm{c}}$ & $4.0 \pm 0.86^{\mathrm{c}}$ & $6.9 \pm 0.10^{\mathrm{c}}$ \\
\hline $\begin{array}{l}\text { Carboxyl methyl } \\
\text { cellulose }\end{array}$ & 30 & $89.7^{\mathrm{c}}$ & $30.0 \pm 3.67^{\mathrm{c}}$ & $1.4 \pm 0.30^{\mathrm{c}}$ & $7.7 \pm 0.08^{\mathrm{b}}$ \\
\hline Avicel & 30 & $189.2^{\mathrm{c}}$ & $106.7 \pm 6.67^{b}$ & $4.8 \pm 0.30^{b}$ & $6.4 \pm 0.12^{\mathrm{d}}$ \\
\hline Peptone & 37 & $120.5^{\mathrm{d}}$ & $48.4 \pm 4.00^{\mathrm{d}}$ & $2.2 \pm 0.18^{\mathrm{d}}$ & $6.7 \pm 0.15^{\mathrm{c}}$ \\
\hline Casein & 9 & $0.1^{\mathrm{f}}$ & $<0.01 \pm 0.001^{\mathrm{f}}$ & $<0.001 \pm 0.000^{\mathrm{f}}$ & $8.4 \pm 0.20^{\mathrm{a}}$ \\
\hline Rice straw ${ }^{5}$ & 12 & $148.7^{\mathrm{d}}$ & $58.9 \pm 3.56^{\mathrm{b}}$ & $2.7 \pm 0.16^{\mathrm{b}}$ & $7.3 \pm 0.09^{\mathrm{ab}}$ \\
\hline Rice straw ${ }^{6}$ & 12 & $201.1^{\mathrm{c}}$ & $59.6 \pm 4.89^{\mathrm{b}}$ & $2.7 \pm 0.22^{\mathrm{b}}$ & $7.3 \pm 0.08^{\mathrm{ab}}$ \\
\hline Corncob & 12 & $467.0^{\mathrm{b}}$ & $116.9 \pm 12.67^{\mathrm{a}}$ & $5.3 \pm 0.57^{\mathrm{a}}$ & $7.2 \pm 0.11^{\mathrm{ab}}$ \\
\hline Sawdust & 18 & $1.5^{\mathrm{e}}$ & $0.7 \pm 0.22^{\mathrm{c}}$ & $0.1 \pm 0.01^{\mathrm{c}}$ & $7.0 \pm 0.06^{\mathrm{b}}$ \\
\hline Compost $^{7}$ & 24 & $17.4^{\mathrm{e}}$ & $11.1 \pm 2.20^{\mathrm{c}}$ & $0.5 \pm 0.10^{\mathrm{c}}$ & $7.2 \pm 0.10^{\mathrm{ab}}$ \\
\hline Green manure & 9 & $651.0^{\mathrm{a}}$ & $118.2 \pm 7.33^{\mathrm{a}}$ & $5.3 \pm 0.33^{\mathrm{a}}$ & $7.5 \pm 0.05^{\mathrm{a}}$ \\
\hline Pig manure & 12 & $197.0^{\mathrm{c}}$ & $49.8 \pm 3.33^{\mathrm{b}}$ & $2.2 \pm 0.15^{\mathrm{b}}$ & $7.7 \pm 0.06^{\mathrm{a}}$ \\
\hline
\end{tabular}

${ }^{1}$ Mean SD $(n=3)$, in the same row that do not share the same alphabetic superscript are significantly different $5 \%$ level according to Duncan's multiple range test. Two percent of organic matter is added to the soil and the sample is incubated at $30^{\circ} \mathrm{C}$ for 45 days.

${ }^{2}$ Initial substrate $\mathrm{pH}$ is 6.6 .

${ }^{3}$ From birchwood.

${ }^{4}$ From oats.

${ }^{5}$ From the second crop season in 1994.

${ }^{6}$ From the second crop season in 1993.

${ }^{7}$ From rice husk and vegetable wastes.

initial soil $\mathrm{pH}$ was 9.3 or 3.2 . Soil $\mathrm{pH}$ between 6.0 and 7.7 initially showed no difference in methane production.

\subsection{Effect of light intensity on methane emission}

Fig. 6 shows the effect of light intensity on methane emission. Methane emission from paddy soil in light and dark treatments in anaerobic condition was not significantly different at low light intensity $(1,000$ 2,000 Lux for 2-3 h daily). Methane emission rate in aerobic condition with dark treatment was higher than with light treatment after $18 \mathrm{~h}$ incubation. However, there was a significant difference between light and dark treatments in both aerobic and anaerobic conditions at high light intensity $(5,000-7,000$ Lux for $15 \mathrm{~h}$ daily). The effect of light intensity on methane emission in anaerobic condition was slight, but the effect was significant in aerobic condition.

\section{Discussion}

Methane production arises from microbial activity in paddy soil, and sterilization destroys the microbial community and inhibits methane production. Nesbit and Breitenbeck (1992) reported that methane uptake was inhibited in autoclaved soils. The soil $\mathrm{pH}$ had a constant value in sterilized samples during incubation, whereas it decreased in natural soil because of acidogenesis by microbes. The same phenomenon was observed by Novaes (1986) in anaerobic digestion of organic wastes in methane fermentation. Most of the methanogenic bacteria grew at a $\mathrm{pH}$ near neutral with a range of 6.5-7.5 (Mah and Smith, 1981), methane production decreased when the $\mathrm{pH}$ was too high or too low (Wang et al., 1993). The final $\mathrm{pH}$ values of glucose, sucrose, cellobiose and starch were below $\mathrm{pH}$ 5.0, whereas the final $\mathrm{pH}$ of casein exceeded 8.0. Therefore, both of them had negligible effects on 


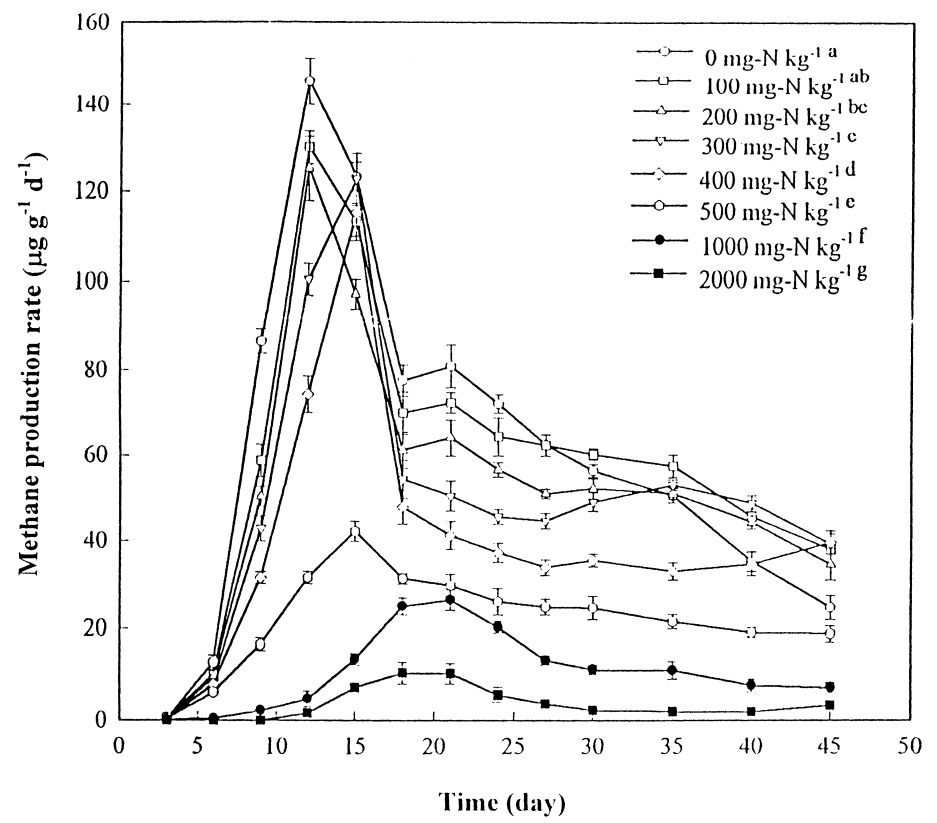

Fig. 3. Effect of urea application on methane production rate. Symbol labels in the figure that do not share the same alphabetic superscript are significantly different at $5 \%$ level according to Duncan's multiple range test.

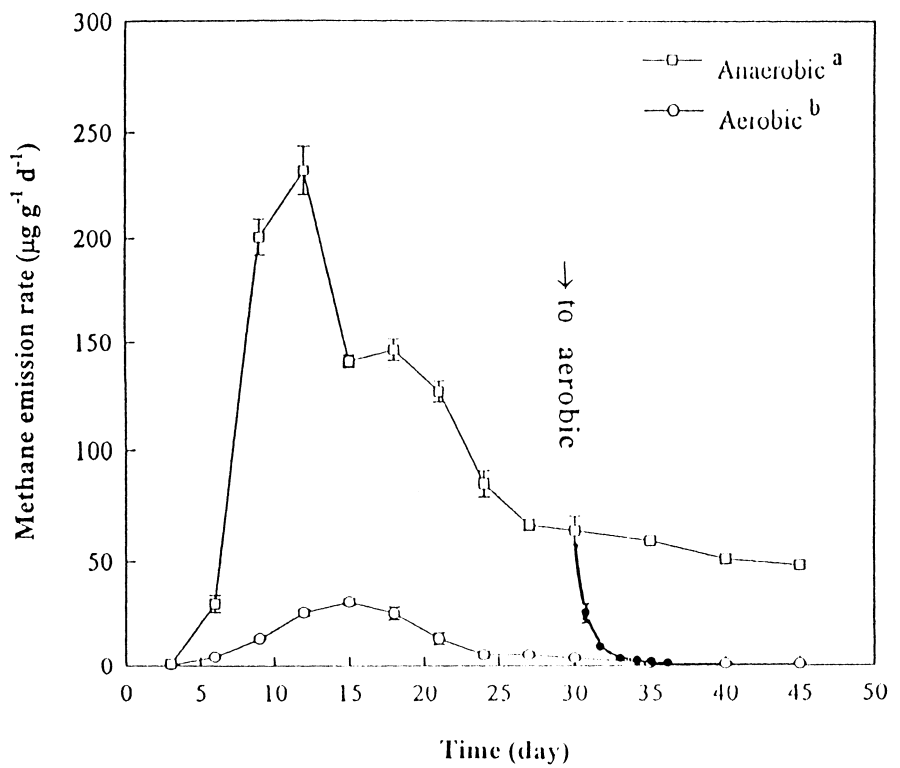

Fig. 4. Effect of anaerobic and aerobic conditions on methane emission rate from paddy soil. Part of the samples were flushed with air after 30 days incubation under anaerobic conditions as the arrow indicates. Symbol labels in the figure that do not share the same alphabetic superscript are significantly different at 5\% level according to Duncan's multiple range test. 


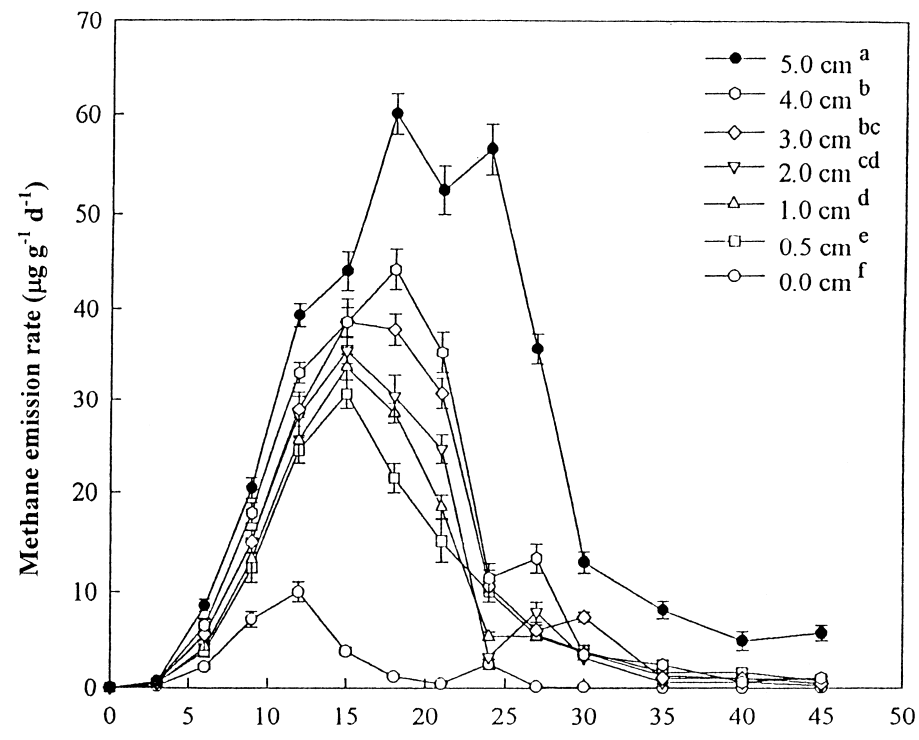

Time (day)

Fig. 5. Effect of the depth of flooding water (0-5 cm depth) on the surface of soil on methane emission rate. Symbol labels in the figure that do not share the same alphabetic superscript are significantly different at 5\% level according to Duncan's multiple range test.

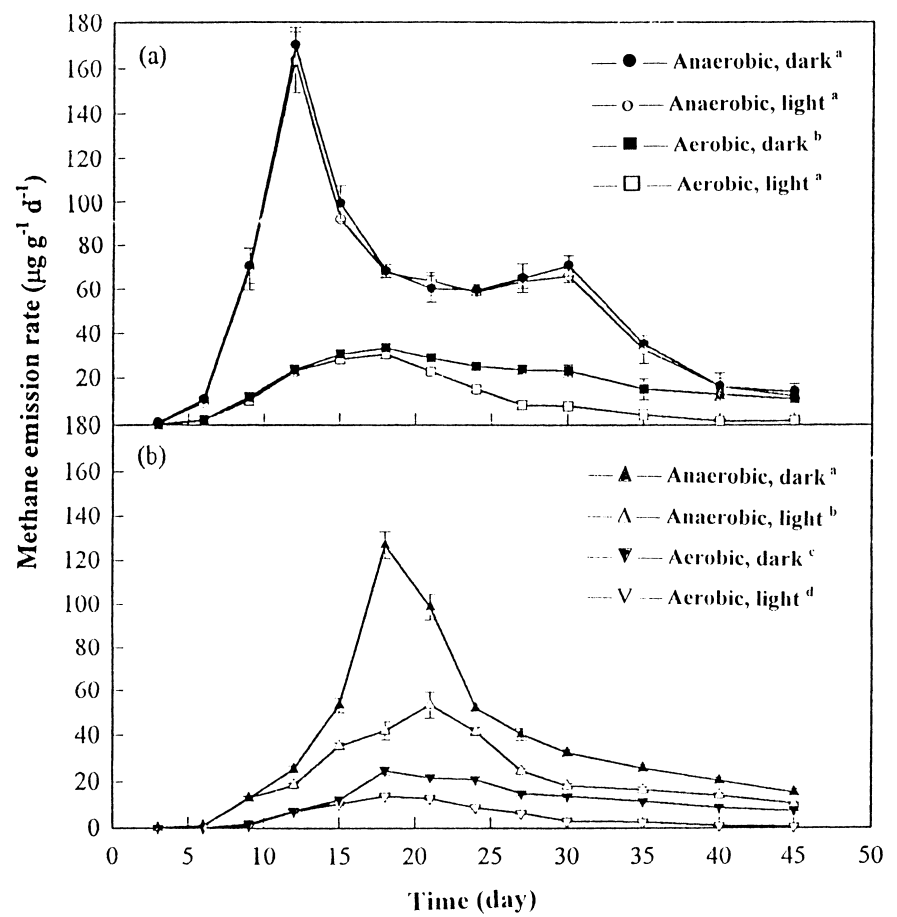

Fig. 6. Effect of light intensity on methane emission rate. Symbol labels in the figure that do not share the same alphabetic superscript are significantly different at $5 \%$ level according to Duncan's multiple range test. (a) 1,000-2,000 Lux for 2-3 h daily at 30 $\mathrm{C}$; (b) 5,000-7,000 Lux for $15 \mathrm{~h}$ daily at $30^{\circ} \mathrm{C}$. 
methane production. Nearly all of the methanogens appear to be stimulated by addition of complex nutrients such as peptone and manure to the culture medium; moderately enhanced by the addition of polysaccharide such as xylan, avicel, carboxyl methyl cellulose, corncob and rice straw; and significantly inhibited by the addition of mono- and di-saccharides such as glucose, sucrose and cellobiose.

Application of urea increased soil $\mathrm{pH}$ and reduced methane production, especially when the fertilizer was deeply incorporated into soils (Wang et al., 1992; Shin et al., 1995). Therefore, application of urea to alkaline soils is unfavourable for methane production. However, in the field, urea application stimulated the growth of rice plants which secreted more organic materials (such as soluble sugars, organic acids and amino acids) to the substratum for use as substrates for methane production. Urea application stimulated methane production in the acidic paddy fields (Murakami et al., 1990; Lindau et al., 1991). In this study, urea application inhibited methane production.

There was a positive linear correlation between total methane production and incubation temperature. Similar results were also observed in the paddy soil of Minnesota (Williams and Crawford, 1984) and Korea (Shin et al., 1995). Two groups of methanogenic bacteria are present in paddy soil, one mesophilic with optimal growth temperature between 30 and $40^{\circ} \mathrm{C}$, and the other thermophilic with optimal growth temperature between 65 and $70^{\circ} \mathrm{C}$ (Mah and Smith, 1981). The optimal growth temperature of the methanogens was around $30^{\circ} \mathrm{C}$ in the paddy soil of Japan (Kimura et al., 1993), and was between 35 and $42^{\circ} \mathrm{C}$ in the sediment of Wisconsin (Zeikus and Winfrey, 1976). In the present study, there were two methane production peaks, 37 and $60^{\circ} \mathrm{C}$. However, there was only one methane production peak when the incubation temperature was shifted from $30^{\circ} \mathrm{C}$ to various incubation temperatures for $24 \mathrm{~h}$. The lack of a significant peak of methane production at $60^{\circ} \mathrm{C}$ might be because the short period $(24 \mathrm{~h})$ of incubation at high temperature was insufficient to adapt the activity of thermophilic methanogens.

Methane production was stimulated with addition of rice straw in Langyang soil, as was also found in Japan (Yagi and Minami, 1990), Louisana (Lindau and Bollich, 1993), California (Wang et al., 1992) and Korea (Shin et al., 1995). The accumulation of low molecular weight fatty acids could lower the soil $\mathrm{pH}$ and inhibit methane production. Huang et al. (1984) demonstrated that large amounts of fatty acids were formed during organic matter digestion in the soil, and methane production was inhibited. In the present study, green manure, pig manure, corncob, rice straw and xylan had a stimulatory effect on methane production, but sawdust and compost only slightly influenced methane production. Methane production rates had 3 peaks at 12th, 24th and 40th day when soil with rice straw amendation was incubated at $30^{\circ} \mathrm{C}$. This phenomenon might be due to the contents of cellulose, hemicellulose, lignin, water soluble sugar and ether soluble lipid. The same result was also observed with straw degradation (Lynch, 1983).

The presence of oxygen inhibited methane formation and emission in the soil (Conrad and Rothfuss, 1991). High concentrations of oxidative inorganic compounds will retard and inhibit methane formation (Bouwman, 1991). The methane production rate decreased very sharply for the air-flush treatment and this would be the result of inhibition of methane formation and the stimulation of methane oxidation (Conrad and Rothfuss, 1991; Nesbit and Breitenbeck, 1992).

Methane production of paddy soil depends on the water content. Flooding treatment enhanced methane production with dry conditions being unfavourable. Similar tendencies were also found in Alaska arctic tundra (Morrissey and Livingston, 1992), wetlands (Shannon and White, 1994) and Korean paddy fields (Shin et al., 1995). Methane production increased with the depth of water flooding on the surface of the test soil. However, the percentage of methane emission to the air was reversed. Percentage of methane emission decreased with the depth of water flooding between 10 to $60 \mathrm{~cm}$ in wetlands of Quebec (Moore and Dalva, 1993) and in arctic tundra (Sebacher et al., 1986). The anaerobiosis of soil increased with the depth of flooding from 0 to $10 \mathrm{~cm}$ and stimulated the methane emission and production. However, the oxidation of methane increased when the depth of water flooding was greater than $10 \mathrm{~cm}$ (King, 1990; Moore and Dalva, 1993; Banker et al., 1995). Therefore, methane emission in the paddy soil could be reduced by using intermittent irrigation during the latter growth stages.

Methane production was slightly affected at low light intensity in comparison with high light intensity. 
Sass et al. (1991) reported that the annual methane emission was positively proportional to the cumulative light intensity in a Texas paddy soil, and King (1990) indicated that methane emission of forest wetland decreased with higher light treatment because of the change of $\mathrm{O}_{2}$ profile in the soil. Methane production in the light treatment under aerobiosis might be the result of growth of algae, and the change of $\mathrm{O}_{2}$ profile in the soil as noted by King (1990). Therefore, light treatment could possibly induce the growth and photosynthesis of algae and the oxidation of methane, but reduce the emission of methane.

\section{Conclusions}

The results show that methane production and emission from the paddy soil were affected by environmental conditions. Methane production increased with the incubation temperature, addition of organic matter and water flooding; its production decreased with sterilization, aerobic conditions, additions of mono- and di-saccharide and urea, and under high light intensity. Water flooding on the surface of soil enhanced methane emission. Appropriate drainage of the paddy soil will reduce methane production and emission.

\section{Acknowledgements}

The authors thank Professors H.C. Lin, Y.S. Wang, R.S. Chung, S.N. Huang and C.M. Lai for their technical assistances and helpful comments, the National Science Council of the Republic of China for financial support (NSC 84-2621-P002-033 and NSC 85-2621-P002-016), and anonymous referees and an Editor-in-Chief for improvements to the original draft of the paper.

\section{References}

Banker, B.C., Kludze, H.K., Alford, D.P., DeLaune, R.D., Lindau, C.W., 1995. Methane sources and sinks in paddy rice soils: relationship to emissions. Agric. Ecosyst. Environ. 53, 243251.

Bouwman, A.F., 1991. Agronomic aspects of wetland rice cultivation and associated methane emissions. Biogeochem. 15, 65-88.
Cao, M.K., Dent, J.B., Heal, O.W., 1995. Methane emissions from China's paddyland. Agric. Ecosyst. Environ. 55, 129-137.

Chang, H.L., Yang, S.S., 1997. Measurement of methane emission from soil. J. Chinese Agric. Chem. Soc. 35, 475-484.

Cheng, K.A., Chiang, C.C., Wang, H.H., 1982. Effect of initial moisture content and temperature on the solid state fermentation of hog faeces. J. Biomass Energy Soc. China 1, 26-31.

Conrad, R., Rothfuss, F., 1991. Methane oxidation in soil surface layer of a flooded rice field and the effect of ammonium. Biol. Fert. Soils 12, 28-32.

Delwiche, C.C., Cicerone, R.J., 1993. Factors affecting methane production under rice. Global Biogeochem. Cycles 7, 143-155.

Ehhalt, D.H., Schmidt, U., 1978. Sources and sinks of atmospheric methane. Pure Appl. Geophys. 116, 452-464.

Gardner, W.H., 1982. Water content. In: Klute, A. (Ed.), Methods of Soil Analysis. Part 1. Physical and Mineralogical Methods, 2nd ed. American Society of Agronomy, Madison, Wisconsin. pp. 493-544.

Huang, S.Y., Chen, C.L., Chian, M.S., Lin, L.T., 1984. Kinetics of acidogenesis and methanogenesis in methane fermentation of hog faeces. J. Biomass Energy Soc. China 3, 26-48.

Kawauchi, H., 1990. Analysis of organic components. (Japan Soil Sciences and Plant Nutrition Society), Experimental Methods of Plant Nutrition. Haku-Bun-Sha, Tokyo, Japan, pp. 204-250.

Kimura, M., Minoda, T., Murase, J., 1993. Water-soluble organic materials in paddy soil ecosystem. II. Effects of temperature on controls of total organic materials, organic acids, and methane in leachate from submerged paddy soils amended with rice straw. Soil Sci. Plant Nut. 39, 713-724.

King, G.M., 1990. Dynamics and controls of methane oxidation in a Danish wetland sediment. FEMS Microbiol. Ecol. 74, 309324.

Lindau, C.W., Bollich, P.K., 1993. Methane emissions from Louisiana first and ratoon crop rice. Soil Sci. 156, 42-48.

Lindau, C.W., Bollich, P.K., DeLaune, R.D., Patrick, W.H., Jr., Law, V.J., 1991. Effect of urea fertilizer and environmental factors on methane emissions from a Louisiana USA rice field. Plant Soil 136, 195-203.

Lynch, J.M., 1983. Microbial saprophytes: decomposition process and nutrient cycles. Soil Biotechnology. Blackwell Scientific Pub., Oxford, pp. 42-59.

Mah, R.A., Smith, M.R., 1981. The methanogenic bacteria. In: Starr, M.P., Stolp, H., Trüper, H.G., Balows, A., Schlegel, H.G. (Eds.), The Prokaryotes. Springer, Berlin, pp. 948-977.

Moore, T.R., Dalva, M., 1993. The influence of temperature and water table position on carbon dioxide and methane emission from laboratory columns of peatland soils. J. Soil Sci. 44, 651664.

Morrissey, L.A., Livingston, G.P., 1992. Methane emissions from Alaska arctic tundra: An assessment of local spatial variability. J. Geophys. Res. 97, 16661-16670.

Murakami, H., Kimura, M., Wada, H., 1990. Microbial colonization and decomposition processes in rice rhizoplane. II. Decomposition of young and old roots. Soil Sci. Plant Nut. 36, 441-450.

Nelson, D.W., Sommers, L.E., 1982. Total carbon, organic carbon and organic matter. In: Page, A.L. (Ed.), Methods of Soil 
Analysis. Part 2: Chemical and Microbiological Properties, 2nd ed. American Society of Agronomy, Madison, Wisconsin. pp. 539-580.

Nesbit, S.P., Breitenbeck, G.A., 1992. A laboratory study of factors influencing methane uptake by soils. Agric. Ecosyst. Environ. $41,39-54$

Novaes, R.F.V., 1986. Microbiology of anaerobic digestion. Water Sci. Technol. 18, 1-14.

SAS Institute, 1988. SAS/STAT User's Guide. Release 6.03 SAS Inst. Cary, North Carolina.

Sass, R.L., Fisher, F.M., Tuner, F.T., Jund, M.F., 1991. Methane emission from rice fields as influenced by solar radiation, temperature and straw incorporation. Global Biogeochem. Cycles 5, 335-350.

Sebacher, D.I., Harriss, R.C., Bartlett, K.B., Sebacher, S.M., Grice, S.S., 1986. Atmospheric methane sources: Alaskan tundra bogs, an alpine fen, and a subarctic boreal marsh. Tellus 38, $1-10$.

Shannon, R.D., White, J.R., 1994. A three-year study of controls on methane emissions from two Michigan peatlands. Biogeochem. 27, 35-60.

Shin, Y.K., Lee, Y.S., Yun, S.H., Park, M.E., 1995. Methane emission measurement in rice paddy of Korea. The Proceedings of International Symposium on Environment and Biometeorology. China Agricultural Scientech Press, Beijing, pp. 495503 .
Wang, Z.P., DeLaune, R.D., Lindau, C.W., Patrick, W.H., Jr., 1992. Methane production from anaerobic soil amended with rice straw and nitrogen fertilizers. Fert. Res. 33, 115-121.

Wang, Z.P., DeLaune, R.D., Masscheleyn, P.H., Patrick, W.H., Jr., 1993. Soil redox and $\mathrm{pH}$ effects on methane production in a flooded rice soil. Soil Sci. Soc. Am. J. 57, 382-385.

Williams, R.T., Crawford, R.L., 1984. Methane production in Minnesota. Appl. Environ. Microbiol. 47, 1266-1271.

Yagi, K., Minami, K., 1990. Effect of organic matter application on methane emission from some Japanese paddy fields. Soil Sci. Plant Nut. 36, 599-610.

Yang, S.S., 1998. Methane production of river and lake sediments in Taiwan. Environ. Geochem. Health, 18 (in press).

Yang, S.S., Chang, E.H., 1997. Effect of fertilizer application on methane production in paddy soils of Taiwan. Biol. Fertil. Soils $25,245-251$

Yang, S.S., Chang, H.L., Wei, C.B., Lin, H.C., 1991. Reduce waste production in the Kjeldahl methods. J. Biomass Energy Soc. China 10, 147-155.

Yang, S.S., Lin, C.C., Chang, E.H., Chung, R.S., Huang, S.N., 1994. Effect of fertilizer, soil type, growth season on methane production and emission in the paddy soils of Taiwan. J. Biomass Energy Soc. China 13, 68-87.

Zeikus, J.G., Winfrey, M.R., 1976. Temperature limitation of methanogensis in aquatic sediments. Appl. Environ. Microbiol. 31, 99-107. 